\title{
Examining the Dilemma between Theory and Epistemology of ISP Knowledge for Secondary Liability
}

\author{
Mohammad Sadeghi ${ }^{1}$ \\ ${ }^{1}$ Law School, Brunel University, London, UK \\ Correspondence: Mohammad Sadeghi, Law School, Brunel University-London, UK. E-mail: \\ Mohammad.sadeghi@brunel.ac.uk
}

Received: September 6, 2013 Accepted: September 25, 2013 Online Published: February 28, 2014

doi:10.5539/jpl.v7n1p1 URL: http://dx.doi.org/10.5539/jpl.v7n1p1

\begin{abstract}
Holders of rights sue the intermediately service providers (ISPs) for contributory liability through the ISPs knowledge of infringement specifically for copyright infringement trademark and other rights. Formalism in the light of corrective justice strictly limits ISPs liability to fault based liability theory, but to evaluate ISPs fault gives credit to the probabilistic knowledge that requires ISPs to serve as the police for owners of rights. Furthermore, they are for establishing corrective justice law applies the mathematics though on the knowledge of fault via attempts to achieve all of the answers regarding the measure of evaluating ISPs' knowledge from secondary liability rather than computing philosophy, social science, or realism. Other common theories recognize chief justice brain or reasonable man mind induced as critical of ISPs' knowledge of infringement. This is in contrast with computing mind philosophy. Research will answer inconsistency of theories and ISP knowledge to protect all parties' rights.
\end{abstract}

Keywords: intermediately service providers (ISPs), secondary liability, formalism, reasonable man mind, computing knowledge

\section{Introduction}

Nowadays, secondary liability rules a range of diverse activities including copyright and trademark infringement to shield the user rights, service providers, and exclusive right holders (Werner Z. Hirsch, 1988 p.165; Patrice Jourdain2007 p.9; SaidMortaza Qasemzadeh, 2008 p136; International Encyclopaedia of Comparative Law, 1983 para 196) (Note 1). It has become more prevalent owing to technological advancements (Noblett, Pollitt \& Presley, 2000) (Note 2) and it has manifested a significant revelation in ISP liability regime, since that time secondary liability (for ISP) has moved away from giving more attention to ISP strict liability towards liability based on- fault for copyright infringement in US. (Playboy Enterprises Inc. v. Netscape Communications Corp, 2004) (Note 3). This change which focuses on knowledge about the infringement as a legal factor of secondary liability so as to protect parties' rights in online services (Ahmad, 2011; Koster \& Jurgens; Resenberger, Sussman $\&$ Silberberg, 2011) (Note 4). Therefore, to a co- existence between parties' rights, this gives rise the following questions; Is it time to rely on the common theories (secondary liability with reasonable man mind)? Is it time to give importance to computing philosophy of knowledge? To answer these questions, this study would examine the current theories in light of formalism and instrumentalism first and then would discuss the epistemology of knowledge.

\section{Common Theories and Knowledge Standard for Secondary Liability}

Common theories state that the aim of secondary liability is to establish justice between parties or to act as an instrument for corrective justice to correct imbalances caused by one party's breach of duty to another (Heidt, 1990; Cane, 1997; Donoghue v. Stevenson, 1932) (Note 5). The concept of corrective justice is an element found in all common theories: theories based on formalism, theories based on strict liability, and theories based on both fault and instrumentalism. Among these theories, formalism, the theory of liability based on fault and instrumentalism are in scope of this paper regarding the ISP knowledge standard for secondary liability.

\subsection{Formalist Theory and Knowledge Standard for Secondary Liability}

The formalist theory (also called mechanical jurisprudence) (Tamanaha, 2009) (Note 6) is a common legal theory that began in the $19^{\text {th }}$ century in the US (Michael, 2001) (Note 7) as an application of norms to facts. Formalists 
have viewed the law from the normative approach or as a system that stems from Aristotle's logic. Formalists believe that to identify the basics of law, we first need to delve inside the law to find out the legal principles and sub-principles (Ansarie, 2012). Then, the principles and their sub- principles must be arranged in a logical form so that decisions can be made. In other words, results rest on a relatively closed set of logically organised rules (Guthrie, Rachlinkski, \& Wistric, 2007; Tamanaha, 2009; Black Law Dictionary, 2011) (Note 8). Given the above rules, formalism to define the knowledge of infringement to impose secondary liability only relies on the interpretation of legal texts; they are assessed any knowledge standard with the view of "what the law should be" rather than "what the law says" (Guthrie, Rachlinkski, \& Wistric, 2007). The formalist theory is not interested in any secret hidden meaning for establishing knowledge standard the same as the positivism (Fuller, 1976) (Note 9). They apply internal justification to define the targets of liability and observe the knowledge requirement system as illustrated by Kant, Aristotle, and Weinrib which would be addressed in below (Badinie, 2005; Stone, 2002; Leiter, 2000; Hart, 1961; Cooper-Stephenson \& Gibson, 1993) (Note 10).

\subsubsection{Kantianism}

A significant aspect of Kantianism is that liability is based on fault (intentionally and non-intentionally), rather than causation of damage. Knowledge of infringement has been recognised in the light of fault based liability in Kantianism as Kant theory illustrated that the causation of damage (non-fault liability) is not compatible with secondary liability and liberty because liability without fault leads, as Hegel puts it, to "only the negation of a negation of action, not a negation of action itself" (Hegel, 1967; Badinee, 2005). Moreover the focus of his theory on right and duty in the light of liberty to expose liabilities rather than compensate for injuries can prove existence of knowledge as term of fault (Weinrib, 1987) (Note 11). In this regards, 'right' has been defined as the "sum of conditions under which the choice of one can be united with the choice of another in accordance with a universal law of freedom" (Kant, 2008). However, although Kantianism has recognised the knowledge about direct infringement by denying the causation of damage, its efficiency is in question due to implementing the reasonable man mind test for evaluating knowledge. It evaluates the ISP knowledge with "should know" or has "reason to know" in the light of actual and constructive knowledge about user infringement. Furthermore, it scope is bended to the 'person' (Bdeniee, 2005) (Note 12) and does not applicable to 'objects' (ISPs) due to the lack of an imputation object. Likewise, the scope of duty is limited to positive acts and does not recognise omissions, as Kant stated that omission of damage is not a duty, even if there is knowledge of damage which such limitation could affect the owner right who is participating in the virtual world.

\subsubsection{Aristotle's}

Aristotle's view involved restoring the parties, as nearly as possible, to the positions they held before the injury as liability in corrective justice through secondary liability falls on the injurer (Holmes, 1881; Coleman, 1986; Weinrib, 1988). Aristotle focused on arithmetical equality in secondary liability law rather than giving attention to the special value or social position of the injurer (Cooper-Stephenson \& Gibson, 1993). In his view, the injurer (A) is obliged to pay to the injured (B) the value that he took from B by damaging B's assets. Aristotle paid more attention to the causation of damage rather than knowledge about infringement (Fletcher, 1993; Coleman, 1987) (Note 13). He argued: "The law looks only at the nature of the damage, treating the parties as equal, and merely asking whether one has done it and the other has suffered injustice, whether one has inflicted and the other has sustained damage" (Badeniee, 2005).

It sounds as if Aristotle's 'causation' concept is like retaliation in corrective justice. It has been expressed by Pythagoras that if A inflicts damage on B, B can do the same to A. Apparently, the performance of both the arithmetical approach (in both of Aristotle's corrective justice categories: general justice or particular justice) and Pythagoras's retaliation approach can be led liability without knowledge because they assumes that the knowledge exists in the concept of 'a voluntary act' (Gordley, 1995) (Note 14). However, this seems not appropriate because assuming knowledge through a voluntary act does not cover the secondary liability of negligence when an ISP infringes copyright or other rights by negligence. Therefore, establishing a fit between Aristotle's 'causation' concept and ISPs' secondary liability sounds unmanageable, as the former does not recognise knowledge of infringement as an element to establish corrective justice (Ames, 1908).

\subsubsection{Weinrib's Theory}

Ernest Weinrib, as a pioneer of formalism, applied secondary liability to establish Aristotle's concept of corrective justice. In this theory, secondary liability has a special internal system and a reciprocal relationship that exists between the injured and the loss (Perry, 1992). According to his theory, corrective justice is a task for the legal formalist, who has to make explicit the intelligibility that is latent in the legal materials and to indicate which legal error is a deviation (Hutchinson, 1988-1989). For this reason, to provide an appropriate knowledge 
standard for ISPs' secondary liability for prevent infringement in harmony with this theory, attention to the internal dialectics of secondary liability (in corrective justice) and the reciprocal relationship between the injured and the loss is required. This is because secondary liability (tort) has been considered as needing an evaluation that is based on 'why it is' what it is from 'within' and not from the 'outside' appearance. For example, to understand mathematics, one needs to investigate the intricacies of mathematics and its functions by understanding mathematical formulas. Hence, investigating the internal rationality of secondary liability is vital in order to understand secondary liability (Weinrib, 1995) (Note 15).

According to Weinrib's theory, secondary liability is non-political in its nature and aims and the law is not allowed to use liability as an instrument for political, social, and economic purposes. They applies subjective criterion of negligence instead of an objective one to assess ISP knowledge about user infringement to impose secondary liability while subjective criterion of negligence in secondary liability law is a feature of behaviour and mental state that is reprehensible ethically. Weinrib's subjective criterion of negligence places emphasis on the mind of the injurer. As a result, using a subjective criterion of negligence for the knowledge requirement might lead to establishing corrective justice and equality but its components (i.e. personal features and the moral status of damage) affect justice because they rely on the adage "do unto others as you would have them do unto you". This foundation leads to prevalent injustice because of its capability to impose duty to another without giving him rights.

In contrast, the objective criterion of negligence applies a "duty of care" in the light of wisdom, custom, and acts and specific knowledge or knowledge of the injury (White, 1993). The subjective criterion of negligence delimits the types of injury because any damage is not compensable and any benefit does not have secondary liability (it only recognises normative or non-factual profit) (Weinrib, 1993). Thus, appropriateness of their rule to use a subjective criterion of negligence for evaluating the ISP knowledge standard for secondary liability is open to question due to criteria and their attention on the internal massage of secondary liability for establishing corrective justice. Furthermore, their focus on the victim and the compensation, rather than the injurer's rights (Hershovitz, 2011) which can make barrier for establishing a knowledge standard in harmony with the parties' rights due to the lack of equal value between the victim rights and those of the injurer (Berry, 1999) (Note 16). In line with that implication of negligence with reasonable man mind test criteria rises ISP duty of care and its chance to be held liable without knowledge due to the possibility of different interpretations.

\subsection{Fault Based Liability Theory}

Fault in the form of a knowledge requirement was "one of the conquests of civilization" (Note 17) that began in the $18^{\text {th }}$ century and developed further in the $19^{\text {th }}$ century. No liability without fault has been developed by common law and civil law. Moreover, legal scholars have replaced liability without fault (or liability for causation and the 'but for' test) with liability in the form of fault which consists of knowledge requirements (Tunc, 1976; Prosser, 1971; Qasemzadeh, 2008) (Note 18).

Pioneers of the fault theory believe in establishing corrective justice and reforming distributive justice, which have been damaged by the injurer (Owen, 1995), and so we need secondary liability with fault grounds. Pioneers of the fault theory believe that fault with a knowledge term leads to expose equality and liberty between both parties, due to the dependency of the knowledge criterion on social measures. The knowledge elements required for recognising fault are truth and justified true belief. Therefore, no knowledge is equivalent to no fault (Note 19). Fault based liability evaluates knowledge of injurer based on the reasonable man behaviour in form of social behaviour criterion and corporal criterion. Social behaviours are measured through a delineated knowledge requirement within the scope of the actions of a 'reasonable man', which is more in line with the current goals of secondary liability (which aim to give more value to deterrence than to compensation). Although the social behaviour criteria has above advantages, their application for evaluating the knowledge of ISPs seems open to debate because the social behaviour criteria for evaluating a 'reasonable man' have applied diverse approaches, for instance in utilitarianism, which unreasonable behaviour is an action that one never wants for oneself. Injurer behaviour is also unreasonable when the cost of the risk of an action is more than the social profit from the action (economic efficiency). Furthermore, they evaluate the knowledge based on the situation i.e.; different criteria for different situations, courts use different methods and criteria to define a 'reasonable man', his social behaviour, and the value of causes (Osborne v. Montgomery, 1931). For instance the courts' criteria depend on altruism and equal liberty, standard utilitarianism, and economic analysis. Therefore, reasonable behaviour should be analysed according to who did what, for whose benefit, and who the victim is. Moreover, the position of consent varies in different situations, instead of following fixed criteria (Note 20). 
As a consequence, evaluating the knowledge of infringement based on fault based liability with the behaviour of a 'reasonable man' poses various criteria for evaluating the knowledge of infringement. Most of them are closely related to the state of mind and do not pay attention to the social role of the injurer's behaviour and the role of technology (like ISPs) (Conaghan, 1996; Bender, 2011). Thus, requiring an ISP to combat infringement and provide services based on these criteria seems technically impossible.

\subsection{Instrument Theory and Secondary Liability}

Instrument theory applies secondary liability to establish utilitarian- or welfare-based perspectives. According to this theory, the law cannot undo the past, but it can apply its role to make a better future by applying secondary liability as an instrument for social welfare (Abdali, 2012). Furthermore, the role of liability has been stated to be for the good of all, not only to provide justice between two parties; in other words, liability at its most efficient benefits society. The instrument theory illustrates the fact that secondary liability (secondary liability) is able to provide incentives for maximally beneficial behaviour and to serve as insurance by compensating for loss as well. It implies that secondary liability (secondary liability) has also been considered as a mixture of markets and morals due to the different bases of secondary liability. Secondary liability is a mixture of grounds for decisions that are drawn from both corrective justice and economics.

In this regard, some scholars (such as Coleman) have also remarked that secondary liability can be based on more than one fundamental principle (Cooper-Stephenson \& Gibson, 1993) and it is an institutional method for giving effect to the principle of corrective justice, but not the only method. Furthermore, the mode of rectification represented by secondary liability, in which injurers are required to bear their victims' losses, must be justified on grounds independent of corrective justice, such as considerations of deterrence and accident/cost avoidance. Thus, economic efficiency should be recognised as supporting existing secondary liability functions.

Overall, in instrument theory, liability values depend on the social goals of society, such as economic aims, compensation, distributing costs and risks between society members, and deterring society members who present non-social behaviour. In addition, secondary liability (secondary liability) has been categorised into secondary liability in economic instrumentalism (an instrument for protecting economic policy) (Colman, 1999; Perry, 1999) (Note 21) and secondary liability in moral instrumentalism (an instrument for addressing social and political aims) (Badinee, 2004) (Note 22). Therefore, based on the above categorisations, once secondary liability as an instrument is not able to answer and protect society's goals (such as social, political, and non-economic goals), society would apply other instruments, because the aim defines the context and form of secondary liability (rather than the secondary liability itself). It has also been applied to distribution of loss (Harrison, 2003) (Note 23), public and private deterrence (Rogers, 2002; Linden, 1993) (Note 24), and other economic functions, for instance secondary liability in the light of the economic approach can make the party or parties who are in the best positions avoid the liability or minimise their losses. In other words, the person makes a decision about whether the benefits of the activity outweigh its costs (Harrison, 2003). Therefore, secondary liability is offered to the producer to internalise liability costs by placing the liability costs on their products, which protects markets from market equilibrium (Badiniee, 2004, p. 85, 86, 89). In line with this, secondary liability is an instrument for striking a balance between social costs and economic costs because it imposes the liability on those who have the ability to prevent damage at a low cost (Bayles, 1987, p. 216). Consequently, according to instrumentalism an appropriate knowledge standard should be in accord with all parties rights and society amis.by having the instrumentalism theory it sounds that having a knowledge standard based on the instrumentalism view seems appropriate than formalism because it does not force knowledge to be limited on the secondary liability context aims, it allows designing a knowledge standard close to realism of technology.

\section{Epistemology of Knowledge}

Knowledge cannot be bounded by one definition due to its wide scope, but it can be seen within the scope of formal/informal, limited/unlimited, and theoretical/practical concepts; in other words, it can be divided into scientific knowledge and situated knowledge. To better understand the knowledge requirement, its epistemology needs to be considered. For this reason, a review is firstly presented of the concept of knowledge for human beings and machines, focusing on mathematical, science, and computer philosophy.

\subsection{Human Knowledge}

To design an appropriate knowledge standard to impose liability, the epistemology of knowledge needs to be understood. In sophistic philosophy, human sense and analogy are manifested as sources of human knowledge (Saljooghi, 2012).This view of human knowledge was criticised by Aristotle and Socrates. They claimed that, depending on the human knowledge, analogy does not prove that those elements that we make an analogy with are true. This is because although analogy has a mathematical base, it does not have any external meaning. For 
instance, if we say that $\mathrm{A}+\mathrm{B}=\mathrm{C}$, the analogy does not show that $\mathrm{A}$ and $\mathrm{B}$ are true by themselves. Before the $5^{\text {th }}$ century, to tackle these challenges, philosophy paid attention to the internal sense rather than the external sense. Subsequently, scepticism, experimentalism, and new Platonism appeared and they presented intelligence, sense, and wisdom as the sources of human knowledge. Platonism states that knowledge is equivalent to "justified true belief" (Turri, 2012), but it is not clear what is meant by 'true' and 'belief'. In line with this, in modern philosophy (rationalism and empiricism), knowledge has become systematic through scepticism. When associated with $17^{\text {th }}$-century thinkers such as Descartes, Spinoza, and Leibniz, word rationalism used to mean a belief in reason was the only valid source of knowledge. Descartes, as the father of scepticism, pointed out that human beings achieve knowledge through scepticism. In this regard, Kant, as a follower of Descartes, combined both the rationalism of Descartes and the empiricism of Hume as idealism. He believed that the mind is like the gloss on the eyes that leads to making a wall between reality and fact. Therefore, knowledge has its roots in empiricism. In contemporary philosophy, discussions on the source of knowledge have moved from idealism to realism, in the light of pragmatism, science and non-science, and existentialism.

Consequently, a similar point in all philosophical approaches is that human knowledge has a link with prior knowledge and culture and expectations (Note 25). A person's prior knowledge is undeletable knowledge that has an effect on human understanding and comprehension, in contrast with the knowledge of a machine (Burk, 2012).

\subsection{Machine Knowledge}

In a similar way to the philosophy of human knowledge, the philosophy of machine knowledge has been applied both rationalism and empiricism. For instance, traditional empiricism can be seen in software engineering and computer ideas, and human interference and rationalism can be seen in computer methods and theories. Empiricism nowadays has been used in the form of positivism. The belief is that science can prove that some facts are correct, but this raises a number of questions regarding ISPs. Is an ISP able to understand? Is an ISP only able to understand based on a computational theory of the mind? Is an ISP a computational machine that only reads mathematics and does not have any implied cognitive function?

Briefly, according to the computational theory of the mind, ISPs are syntactic and non-pragmatic or semantic (P. Hayes et al, 1994, p. 333). ISPs are only based on mathematics, working within the scope of reading but not comprehension. Their knowledge does not have any link to prior knowledge, even though there is sometimes interference in cognitive science and compensation (Sartor, 2003).

In this regard, the capability of artificial intelligence (McCarthy, 2012) (AI) and its relation to ISPs' knowledge is in question; that is, through AI, are ISPs able to comprehend, understand, or have consciousness? This question can be responded to by the Turing test and the Chinese rooms' method.

The Turing test developed mathematical philosophy and presented new ways of thinking in computer science. It has been used for defining a standard for a machine to be called 'intelligent'. The idea is that a computer can be said to 'think' if a human interrogator could not tell it apart, through conversation, from a human being. The results of the Turing test show that, to date, the capability of a machine to have a mind and understanding is in question (Ravenscroft, 2005; Hodges, 1983).

The Chinese rooms test is a thought experiment method that was devised by Searle (Searle, 2012). Searle explains that there is a program that enables a computer to carry on an intelligent conversation in written Chinese. By using this program, someone who he is speak only English is able to execute the instructions of the program by hand and then the English speaker would be able to carry on a conversation in written Chinese, but the English speaker would not be able to understand the conversation. Similarly, Searle concludes that a computer executing the program would not 'understand' the conversation either. He mentioned that a program cannot give a computer a "mind, understanding or consciousness", even if it works intelligently or behaves intelligently (Note 26).Thus, according to the above tests and computer philosophy, ISPs do not have a "mind, understanding or consciousness" like human beings to work based on the reasonable man mind test, it needs certainty to participate in online society. ISPs' thoughts are complex symbols and their thinking is a calculated process.

\section{Conclusion, Finding and Recommendation}

Corrective justice is vital across all theories. ISP knowledge standards, to be in harmony with those theories needs to pay attention to the internal dialectics of secondary liability (in corrective justice) and to the reciprocal relationship between the injured and the lost. This is because it has been considered that, in order to understand it, we need to evaluate secondary liability based on 'why it is', 'what it is from within' and not from the 'outside' appearance. Internal justification can be applied so as to define the targets of liability and to observe the 
knowledge requirement system, as can be found in the thoughts of some followers of the classical natural theory proposed by Kant, and Aristotle, who applied a formalist approach to define secondary liability.

Formalist ideas involve arithmetical (Perry, 1999) equality in secondary liability law rather than paying attention to the special value or social position of the injurer. In fault-based theory, only social criteria in different situations seem related to the knowledge standards, as these criteria are permitted in order to design flexible measures for evaluating ISPs' knowledge. However, implementing the 'reasonable man' test is still open to debate. The corporeal measures are more focused on causation and the internal meaning of secondary liability. In contrast with these theories, realism (in light of the instrumentalist view about secondary liability) presents economic efficiency and social welfare as elements for designing an appropriate ISP knowledge standard. From this perspective, secondary liability is considered as an instrument for social aims and economic efficiencies; it is considered that a proper knowledge standard is a knowledge standard that is in line with these aims.

Overall, by considering the common theories it was found that the current theories suffer from some weakness concerning the protection of parties' rights (owner, user, and society and ISP rights). Although formalism theory recognizes the secondary liability as a legal approach to establish corrective justice, it has focused mostly on injury and compensation but this is inadequate to establish a knowledge standard which is in line with advance of online infringement and can cooperate with ISPs. Moreover, in terms of injury, they only recognizes the normative and non-factual profit. Also, omission action is not on the formalism right scope. Furthermore, it has relied on the objective negligence which imposes duty of care to ISP to do it by probabilistic knowledge while it opens the door for dominating chief justice Braine. As result, it increases the risk of ISP to be held liable without knowledge. Apart from that, a close analysis of instrumentalism theory seems compatible with epistemology of knowledge in some terms due to possibility of interpreting knowledge of infringement in accord with all parties' rights.

Consequently, based on the findings of this research, it is recommended that law give a credit to differences between human knowledge and machine knowledge for establishing a proper knowledge standard to move from the liability of ISP to responsibility of parties to cooperate with ISP because ISP works with complex symbols and ISP thinking and analysis is a calculated process. ISP is unable to have prior knowledge the same as human to judge all non-algorisms conducts. Therefore, the inability of an ISP to have prior knowledge is an essential element that should be combined with the current theories to have an appropriate knowledge standard for ISPs' secondary liability. In other words, to protect all parties' rights, secondary liability should pay attention to knowledge approach for parties' cooperation instead of more paying attention to the internal meaning of secondary liability or knowledge based on the reasonable man test.

\section{Acknowledgements}

I would like to thank Professor Maurizio Borghi for his extraordinary support during my Ph.D research and Dr Amir Rezaiee for his helpful comments and suggestions.

\section{References}

Abdali, M. (2012). Legal approaches and extra-legal attitudes. Mizan Legal Foundation.

Badinie, H. (2004). Economical Analysis of Secondary liability. Law Quarterly - Journal of Faculty of Law and Political Science. University of Tehran.

Badinie, H. (2005a). Philosophy of tort law. Sahami Publisher Company.

Badinie, H. (2005b). Civil liability. Sahamie Publisher.

Bagher, A. (2012). The Role of the Judge to Develop the Law. Mizan Publishers.

Bender, L. (1993). An overview of feminist torts scholarship. Cornell Law Review, (78), 575. Retrieved from http://www.law.syr.edu/faculty/bender/pubs/overview_fem_torts.pdf

Berry, Ch. (1999). The philosophy of law: An encyclopaedia .Garland Publishing Inc.

Black's Law Dictionary (2nd ed.). Retrieved from http://blacks.worldfreemansociety.org/2/b.htm

Brian, Z. T. (2009). Beyond the formalist-realist divide: The role of politics in judging. Oxford University Press.

Burk, D. L. (2011). Toward an epistemology of ISP secondary liability. Philosophy \& Technology, (24). Retrieved from http://papers.ssrn.com/sol3/papers.cfm?abstract_id $=1920050$

Cane, P. (1997). The anatomy of tort law. Hart Publishing.

Coleman, G. (1981). Corrective Justice and Wrongful Gain. J. Legal Studies, (11).

Coleman, G. (1987). Property Wrongfulness and Duty to Compensate. Chicago-Kent Law Review, (63). 
Coleman, G. (1999). Risk and wrongs: Cambridge studies in philosophy and law (1st ed.). Cambridge University Press.

Coleman, J. L. (1986). The morality of strict liability. Wm. \& Mary Law Review, (18).

Conaghan, J. (1996). Tort law and the feminist critique of reason', in feminist perspectives on the foundational subjects of law (Anne Bottomley ed.).

Cooper-Stephenson, K., \& Gibson, E. (1993). Corrective justice, substantive equality and tort law. Captus University Publications.

David. G. O. (1995). Why philosophy matters to tort law, in philosophical foundations of tort law, in collection of essays. Clarendon Press, 24.

Fuller, L. L. (1976). Anatomy of the Law. Greenwood Press.

George, W. F. H. (1967). Philosophy of Right. T.M. Knox tr, Clarendon Press.

George, P. F. (1993). Corrective Justice for Moderns. Harvard Law Review, (106), 1668.

Giovanni, S. (2003). Cognitive Automata and the Law: Electronic Contracting and the Intentionality of Software Agents. Sparing Science Business Media B. V. Retrieved from http://www.cs.uu.nl/jurix03/sartorpaper.pdf

Gordley, J. (1995). In D. G. Owen (Ed.), Secondary liability Law in the Aristotelian tradition', in philosophical foundations of secondary liability law (1st ed.). Clarendon Press.

Guthrie, Ch., Rachlinkski, J. J., \& Wistrich, A. J. (2007). Blinking on the Bench: How Judges Decide Cases. Cornell Law Review, 93(1), 2.

Harrison, J. L. (2003). Law and economics (3th ed.). Thomson West.

Hayes, P. et al. (1994). In E. Dietrich (Ed.), Human reasoning about artificial intelligence in thinking computers and virtual persons. Academic Press.

Heidt, K. R. (1990). Corrective justice from Aristotle to second order liability: Who should pay when the culpable cannot? Washington and Lee Law Review, 47(2).

Herbert, L. A. H. (1961). The Concept of Law. Oxford University Press.

Hershovitz, S. (2011). Corrective Justice for Civil Recourse Theorists. Florida State University Law Review, (39).

Hirsch, W. Z. (1988). Law and economics: An introductory analysis (Harcourt Brace Jovanovich).

Hodges, A. (1983). Alan Turing: The enigma of intelligence. Hutchinson.

Holmes, O. W. (1951). The common law (44th ed.). Little, Brown and Company.

Hutchinson, A. C. (1988-1989). The Importance of not being Ernest. 34 McGill Law Journal.

International Encyclopaedia of Comparative Law. (1983). Vol XI (2 vols).

James, B. A. (1908). Law and morals. Harvard Law Review, (22).

Jourdain, P. (2007). Principles of civil liability (Majid Adib tr). Mizan Publishers.

Kant, I. (2008). Philosophy of law (Saneie Darebie tr). Majd publisher.

Katozian, N. (2005). Liability of failure products (3rd ed.). Mizan.

Koster, O., \& Jurgens, U. (n. d.) Liability for Links in Germany, Liability of Information Technology Location Tools under German Law after the Implementation of the European Directive on E-Commerce. Hans Bredow Institute Working Paper, 14.

Leiter, B. (2000). Legal realism, in a companion to philosophy of law and legal theory. Blackwell Publishers.

Linden, A. M. (1993). Canadian secondary liability law (5th ed.). Butterworth's.

McCarthy, J. (n. d.). Retrieved from http://www.computerhistory.org/fellowawards/hall/bios/John,McCarthy/

Michael, D. A. F. (2001). Lloyd's Introduction to Jurisprudence (7th ed.). Sweet and Maxwell.

Michael, D. B. (1987). In D. Reidel (Ed.), Principles of law: A normative analysis. Publishing Company.

Michael, G. N., Pollitt, M. M., \& Lawrence, A. P. (2000). Recovering and Examining Computer Forensic Evidence. Forensic Science Communications, 2(4). Retrieved from https://www.ncjrs.gov/App/Publications/abstract.aspx?ID=186015 
Nehaluddin, A. (2011). Computer and internet intermediary liability: A comparative overview. Telecommunications Law Review, (4), 109.

Perry, S. R. (1992). Comment on Coleman: Corrective Justice. Indiana Law Journal, (67).

Popper, K. (2010). All Life Is Problem Solving (Shahryar Khajyan tr, 7th ed.). Maekarz Publisher.

Prosser, W. L. (Ed.). (1971). Hand book of law of tort (4th ed.). West Publishing Co.

Qasemzadeh, S. M. (2008). The foundation of tort. Mizan Publications.

Ravenscroft, I. (2005). Philosophy of Mind: A Beginner's Guide (Hamid Shikh Rezaiee tr). Sarat Publishers.

Religious Technology Center v. Netcom On-Line Communication Services Inc., 907 F. Supp. 1361 (N.D. Cal. 1995).

Resenberger, M. E., Sussman, D. W., \& Silberberg, R. (2010). When Is a Service Provider Liable for Inducement Under Grokster? Intellectual Property \& Technology Law Journal, (22), 6.

Rogers, W. V. H. (2002). Winfield \& Jolowicz on secondary liability (16th ed.). Sweet and Maxwell.

Saljooghi, M. (2012). Some remarks about humans' understanding and the civilization they built, their society and the fault that passes through it. Mizan. 7, 30.

Searle, J. (n. d.). Retrieved from http://socrates.berkeley.edu/ jsearle/articles.html

Stone, M. (2002). In J. Coleman, \& S. Shapiro (Eds.), Formalism, in The Oxford Handbook of Jurisprudence \& Philosophy of Law. Oxford University Press.

Thomas, M. (2009). The philosophy of law: An introduction (Behrooz Jandaqi tr.). Ziton.

Tunc. (Ed.). (1976). International encyclopaedia of comparative law. Vol XI. Torts 13.

Turri, J. (n. d.). 'Is knowledge justified true belief ?' (Forthcoming in Synthese). Retrieved from http://john.turri.org/research/KJTB.pdf

Weinrib, E. (1993). Formalism and its Canadian critics. In K. Cooper-Stephenson, \& E. Gibson (Eds.), Tort Theory.

Weinrib, E. (1995). The idea of private law. Cambridge University Press.

Weinrib, E. J. (1987). Law as a Kantian Idea of Reason. Columbia Law Review, (87) 472.

Weinrib, E. J. (1988). Liberty, Community, and Corrective Justice. Canadian J. of Law and Jurisprudence, 1(3).

White, A. R. (1985). Grounds of Liability: An introduction to the philosophy of law. Oxford University Press.

Yeats, W. B. (1983). In K. J. Finneran (Ed.), Know the Dancer from the Dance: Among School Children in The Collected Poems of W.B. Yeats: A New Edition. Macmillan Publishing.

\section{Cases}

Donoghue v. Stevenson [1932] UKHL 100, [1932] SC (HL) 31, [1932] AC 562.

Osborne v. Montgomery, 234 N.W. 372 (Wis.1931).

Playboy Enterprises Inc. v. Netscape Communications Corp. 354 F3d 1020, 1024 (9 $9^{\text {th }}$ Cir. 2004)

\section{Notes}

Note 1. The origin of the concept of secondary liability has its roots in French, derived in turn from the Latin term torquere, which means 'twisted or wrong'. Generally, "it is a civil 'wrong' which occurs when one party destroys another party's initial entitlement by imposing a negative externality on him." Werner Z. Hirsch, 1998. In early Roman law, a secondary liability fear was liable for any injury he had caused to the victim, whether or not he was culpable. However, this approach was abandoned in classical Roman law, see Qasemzadeh (2008).

Note 2. "The world is becoming a smaller place in which to live and work. A technological revolution in communications and information exchanges has taken place in business, industry, and in our homes"; see Michael G. Noblett, Mark M. Pollitt and Lawrence A. Presley, 2000.

Note 3. Where the court faced the question of the secondary liability rather than the primary liability of the provider; See Playboy Enterprises Inc. v. Netscape Communications Corp. 354 F3d 1020, 1024 ( $9^{\text {th }}$ Cir. 2004); The evolution of secondary liability has been developed by case law and can be noticed in RTC v. Netcom, where the court did not impose a direct infringement on the ISP. Religious Technology Center v. Netcom On-Line 
Communication Services Inc., 907 F. Supp. 1361 (N.D. Cal. 1995). It has also been commented that "Developing countries also should evolve a policy of fault-based liability as this is economically more feasible and also would not affect the rights of citizens"; see Nehaluddin Ahmad, 2011.

Note 4. An ISP can be held liable when knowledge of user infringement or awareness of the infringement exists and the ISP does not react upon receipt of the knowledge; see Oliver Koster and Uwe Jurgens.

Note 5. Concerning the relationship between secondary liability (secondary liability) and distributive justice, there are differences of opinion: some believe that secondary liability law is not within the scope of distributive justice and is best explained through corrective justice or secondary duty. Conversely, others such as Cane argue that "when we take account of the fact that court decisions can create precedents which can be used to guide people's conduct and to decide disputes other than that before the court, we can see that the law of secondary liability is also concerned with distributive justice"; see Peter Cane, 1932.

Note 6. Due to the lack of differences between tort and secondary liability, we applied tort law in the end. In discussing tort law, we describe secondary liability in the form of contributory and vicarious liability and inducement theory. Roscoe Pound's Mechanical Jurisprudence (1908) was seminal in creating the image of judging as an exercise in mechanical, deductive reasoning. Pound began by posing the question: What is scientific law? His answer was that "the marks of a scientific law are conformity to reason, uniformity, and certainty. Scientific law is a reasoned body of principles for the administration of justice, and its antithesis is a system of enforcing magisterial caprice, however honest, and however much disguised under the name of justice or equity or natural law"; see Brian Z. Tamanaha, 2009.

Note 7 . In the $19^{\text {th }}$ and $20^{\text {th }}$ centuries, laissez faire, laissez passer was the dominant system of thought in the US. Formalism (which has individualistic results) has been applied in social science and philosophy with theoretical and empirical reasoning and arguments. However, there has been a move towards considering social science and philosophy as empirical phenomena. The pioneers of this movement in logic and philosophy were William James and John Dewey, whereas Oliver Holmes was a pioneer of legal realism; Michael D.A. Freeman, 2001.

Note 8. According to formalists, "judges apply the governing law to the facts of a case in a logical, mechanical, and deliberative way. For the formalists, the judicial system is a 'giant syllogism machine,' and the judge acts like a 'highly skilled mechanic.' Legal realism, on the other hand, represents a sharp contrast... for the realists, the judge 'decides by feeling and not by judgment; by 'hunching' and not by ratiocination and later uses deliberative faculties 'not only to justify that intuition to himself, but to make it pass muster"'; see Chris Guthrie, Jeffrey J. Rachlinkski and Andrew J Wistrich; Furthermore, 2007, it has been noted that the jurisprudence of conceptions "tends to decay. Conceptions are fixed. The premises are no longer to be examined. Everything is reduced to simple deduction from them, principles cease to have importance. The law becomes a body of rules. This is a condition against which sociologists now protest and protest rightly"; see Brian Z. Tamanaha, 2009. It is worth mentioning that, as pointed out in Black's Law Dictionary, formalism is a "theory that law is a set of rules and principles independent of other political and social institutions"; see Black's Law Dictionary (2nd ed)

Note 9. Cf. Justice Scalia's rejection of intuitionalism: "If you are a textualist, you do not care about the intent, and I do not care if the framers of the Constitution had some secret meaning in mind when they adopted its words"; see http//www.rtbot.net/legal formalism.

Note 10. support internal justification rather than empirical, economic, and social justification; see Badiniee(2005)

Note 11. For Kant, the possibility that law can be systematically right encompasses private law, public law, and international law; it also gives law its normative character as a condition of freedom under which public compulsion is justified; see Ernest J. Weinrib, 1987.

Note 12. A person is who he has imputation for his act. Kantianism liability is applicable to the 'person' and is not applicable to 'objects' (ISPs) due to the lack of an imputation object. Moreover, the scope of duty is limited to positive acts and does not recognise omissions, as Kant stated that omission of damage is not a duty, even if there is knowledge of damage. In Hegel's view, knowledge standards must be line with duty and must not force others to avoid emission of damage when it is not in their duty; see Badiniee, 2005

Note 13. In contrast with this, however, is Pythagoras's belief that retaliation establishes corrective justice (if A inflicts damage on B, B can do the same to A), but it seems that the arithmetical and retaliation approaches are non-performance approaches; see George P. Fletcher, 1993.

Note 14. Aristotle's general view on justice is the 'whole of virtue' approach. Aristotle further divides justice into distributive justice and corrective justice; see Heidt K.R,1990. 
Note 15. Weinrib illustrates that the secondary liability format is arranged by an internal and dependent system. Secondary liability in the internal system uses the instrument of private law and not public law because "the purpose of private law is to be private law". Weinrib1995.

Note 16. Consequently, the formalist attitude to secondary liability is based on an internal understanding and a non-instrumentalist attitude, which looks to establish formalist justice and equality between parties. Moreover, it is more based on Aristotelian and Kantian thoughts. According to those beliefs, secondary liability intends to provide corrective justice (as it is called by Aristotle) or commutative justice (as Aquinas calls it) through an internal system. Some current writers use the phrase 'certificatory justice' or 'reparative justice'; Christopher Berry1999.

Note 17. Roast said "fault was one of the conquests of civilization". Fault is the same as faute in French, which in English is called negligence or blame. Even in common law, there are differences in secondary liability between negligence and fault because negligence does not cover intentional fault, whereas fault covers both intentional and non-intentional fault.

Note 18. The fault liability approach is more based on the moral approach (as pointed out in instrumentalist and formalist theories) because of its function, which imposes liability on the one who committed the fault; Tunc (1976). Fault liability in common law has two sets of criteria: objective criteria and subjective criteria. Objective criteria are based on the 'reasonable man' criterion; see Qasemzadeh 2008. Savatier defined it as a breach of duty by a guilty party who could have appreciated and fulfilled the duty;see Tunc . In contrast, Prosser pointed out that "fault is conduct which involves an unreasonably great risk of causing damage or more fully conduct which inflicts risks below the standard established by law for protection of others against unreasonably great risk of harm". Based on his definition, a breach of previous obligations must satisfy the following terms: it must be an acceptable injury, not foreseeable and actual, a direct injury, and a non-reaper injury; see W. L. Prosser, 1971.

Note 19. Non-fault liability or strict liability in some cases has even been manifested as an instrument to fulfil tort law aims. However, the extension of strict liability to all types of damage does not correspond to philosophy, as the aforementioned aims of the development of a general non-fault scheme of compensation are not in line with the deterrence of damage aims and economic rules of tort.

Note 20. The position of consent varies in different situations: (1.) Personal or third-party benefits: the injurer's infliction of risk injures the victim to gain benefit for him or for a third party. Although the injurer's act benefits the victim (who is not meant to receive any profit from the injurer), his action is not the behaviour of a 'reasonable man' because the injury is foreseeable and the common people would never accept such risks. (2.) Society's interests outweigh the criteria: if the injurer's action has a benefit to society, evaluating the behaviour of a 'reasonable man' is done based on the level of risk (whether the action had a serious and high risk to others). The level of risk (which outweighs personal interests) would be compared to the level of society's interests, so if the society's interest is higher than the personal interest, the injurer's behaviour will be recognised as that of a 'reasonable man' and the injurer is not liable. It is the same circumstances as when an injurer does not have knowledge of the injury. (3.) Victim's interest - infliction of risk: the injurer acts in the victim's interest. Therefore, the injurer's act is a reasonable action due to its links with the risk-interest criterion and equal liberty. (4.) Paternalistic: the injurer acted paternalistically in the victim's interest but without the victim's consent: the injurer did not inform the victim about the consequences of the risk. The injurer's behaviour is not reasonable behaviour, due to its conflict with equal liberty (although there are some exceptions, for example in the patient-centred or physician-centred medical practice standards (these are standards in the UK))

Note21. There are other criteria such as easy rescue and non-easy rescue; see Ken Cooper-Stephenson and Elaine Gibson, 1993.Coleman,

Note 22. Kant and Helime, who have explored secondary liability, might respond that the aims have social value but that this does not mean that secondary liability obtains its value from such aims, see Badiniee, 2004.

Note 23. There is a belief that distribution of loss in society has a positive effect on society's economic plans and has a corrective justice rule among society's members. Secondary liability (secondary liability) decries the fear of obligation and such fear leads to the development of social insurance and liability insurance. For instance, secondary liability makes a company insure its staff via adding the cost of such liability as a production cost. Secondary liability as an economic instrument helps companies to distribute their loss among customers instead of companies suffering. According to the aims of distribution, to offer any knowledge standard, the law should pay attention to the capability of the knowledge standard to fulfil these aims. Calabresi, in the light of costs of accidents, defines three types of costs: primary costs, such as costs which are associated with the harm; secondary types of costs, which are social costs; and tertiary costs, which are costs associated with administering the secondary liability system, see Jeffrey L. Harrison. 
Note 24. In terms of the deterrence aims of secondary liability, secondary liability law has applied and modified some level of fault and attempted to create a balance between fault and compensation. Colman

Note 25. The weakness is that in relation to prior knowledge, scientists share their statements rather than the facts that they have seen.

Note 26. This is against the philosophical positions of functionalism and computationalism, which believe that the mind may be viewed as an information processing system operating on formal symbols.

\section{Copyrights}

Copyright for this article is retained by the author(s), with first publication rights granted to the journal.

This is an open-access article distributed under the terms and conditions of the Creative Commons Attribution license (http://creativecommons.org/licenses/by/3.0/). 